\title{
WILD LIFE IN INDIA
}

\author{
by Jagdish Aggarwal, Regina
}

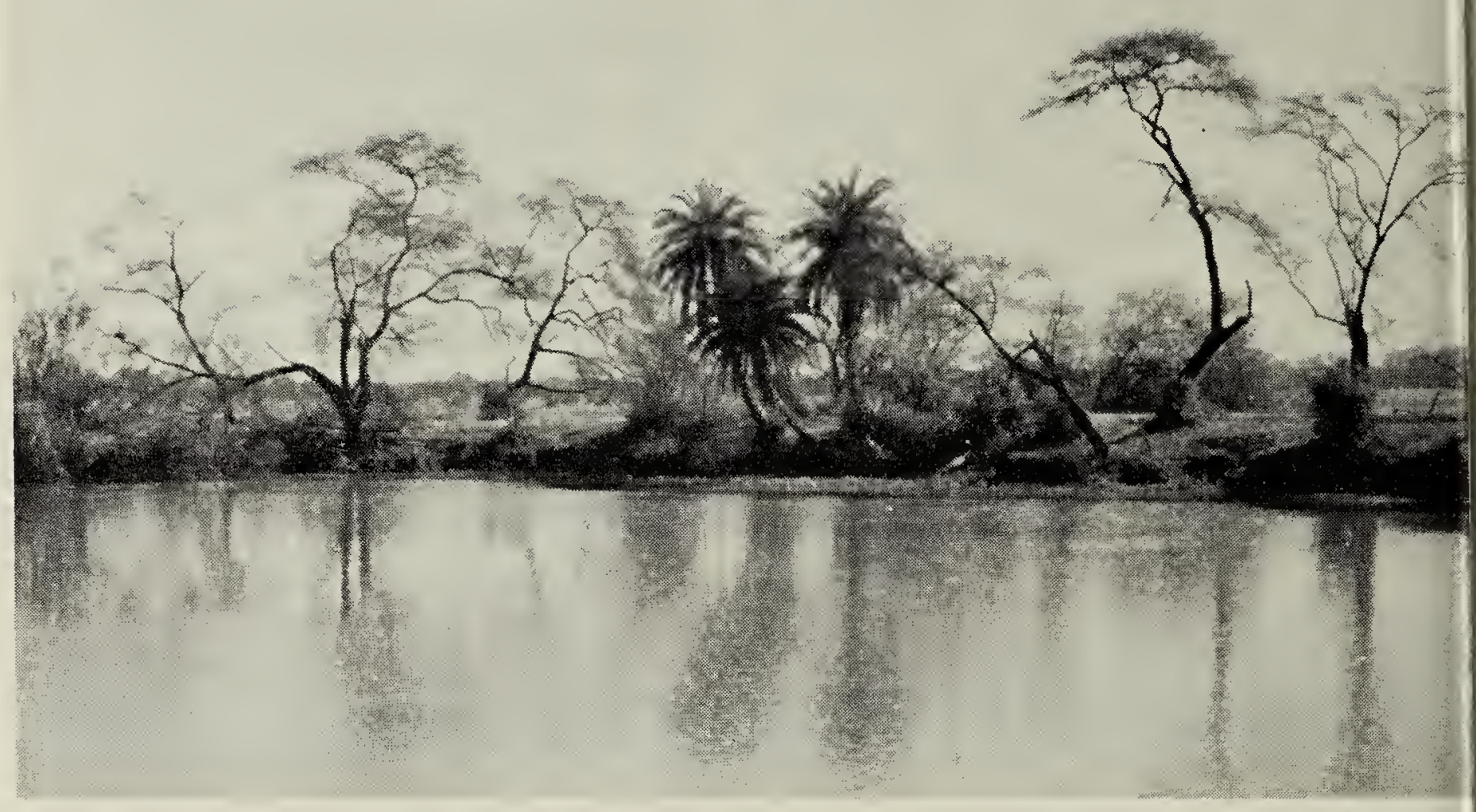

Photo, 1965, Lucy H. Murray

India's Keoladeo Ghana bird sanctuary. For more details of this sanctuary see the Bruce S. Wright article in Canadian Audubon, May-June, 1968.

Nature has lavishly bestowed on Indian soil a luxuriant wild life. Indeed India is one of the few countries on the globe to possess such an abundance and variety of animal life; the diversity of this great country is reflected in its varied fauna. But this abundant fauna, scattered over the length and breadth of the country from the snow-clad peaks of the Himalayas to the cloudy waters of Cape Comorin on one side and from Jaisalmer to Kohima on the other, has received not only a wilful neglect but also an unfair treatment, resulting in the fast depletion of India's animal resources.

In the country in which the teaching of non-violence by Buddhism and Jainism flourished and where Gandhi and Ashoka exhorted people to treat animals humanely, many Maharajas and Nawabs-the rulers of small states in pre-independent India-vied with each other in the wanton destruction of wild life. British civil servants offered rewards for the elimination of flying foxes and monkeys in Kangara District (Himachal Pradesh) and wild boars and nilgai in Gurgaon District (Haryana).

Rapid increase in human population and consequent pressure on food and living space caused spectacular changes in the physical condition of the environment, and the replacement of forests by arable land like that of the Dandakaranya Project, and of fields by human abodes, reduced the area for the free movement of the wild animals. "Grow more food" campaigns were by and large misinterpreted by farmers who used insecticides and other poisons not only for stray pigs, mad dogs, rogue elephants and child-lifting hyaenas but indiscriminately for other harmless and innocent wild animals. Wild life main- 
tenance was also affected by the pollution of soil or water.

The crocodile which once upon a time was fairly generally distributed in the tanks and rivers throughout India is now represented by only a few survivors like those in Pushkar Lake near Ajmer (Rajasthan). The feverish search for their skin, like the search for the feathers of the Passenger Pigeon, speedily decreased their numbers. The 25 tigers of the erstwhile Wankaner State (as estimated in 1947) have now been completely wiped out. The number of tigers has become appreciably low along the Aravelli ranges, and the Indian cheetah-the hunting leopard-has probably ceased to be. The deer, pig, antelope and gazelle in Madhya Pradesh have surrendered to the flashlights and machine guns. Cheetal and bark deer have been tamed and imprisoned in the National Parks to remind visitors of the heavy toll taken of them by man. The musk deer of Himachal Pradesh have largely been ensnared and voraciously devoured. Herds of deer have become a rare sight in Mohindergarh District, as has

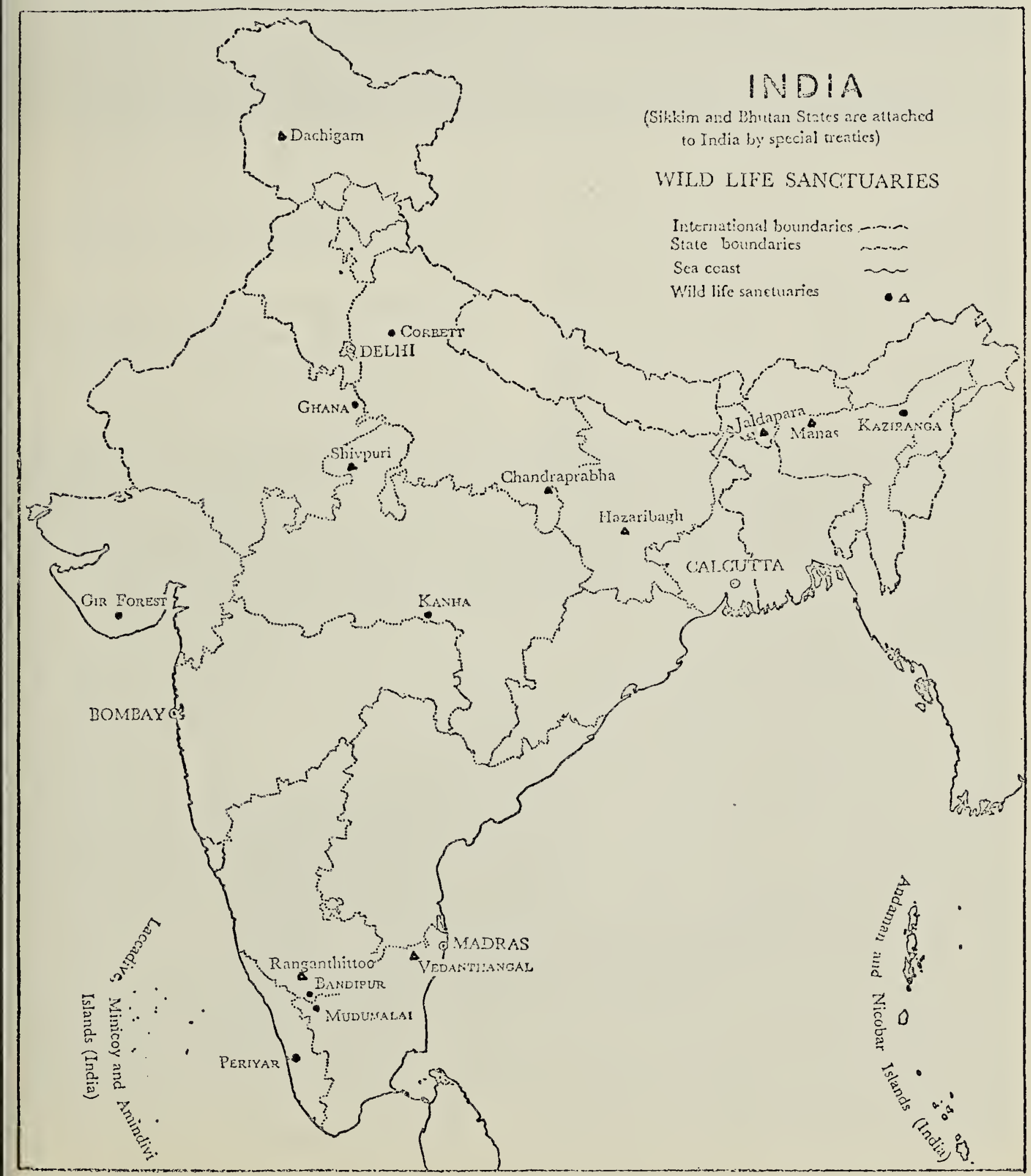




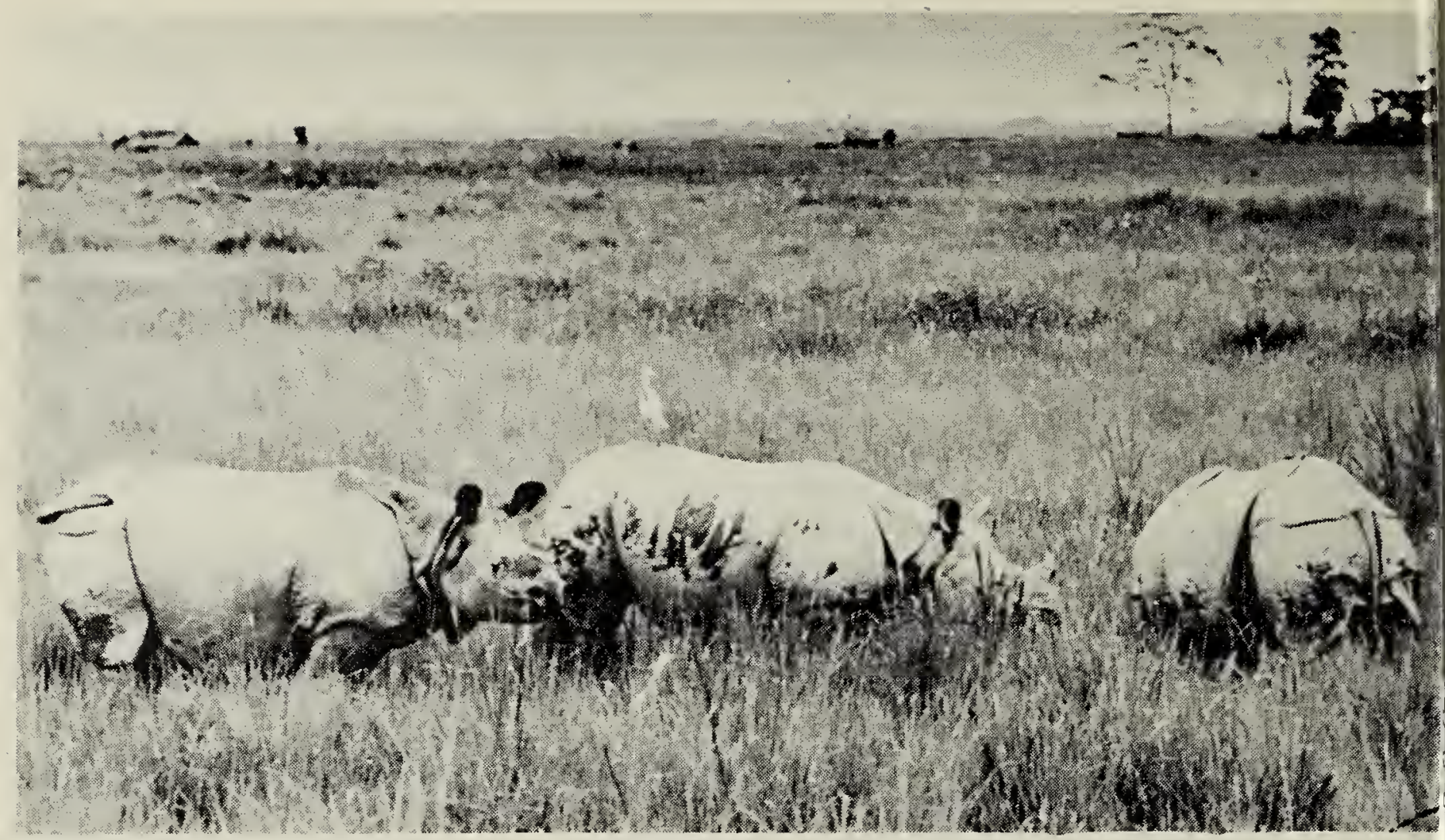

Rhinocesos at Kaziranga Sanctuary (Assam).

Government of India photo

the Kashmir stag, and the brew antler deer is confined to the eastern part of the country. The wild bear of Gujrat. Golden Eagle, Indian wild ass, snow leopard and Indian Bustard are being forced into the groups of extinct animals. The same fate has perhaps befallen to the Bearded Duck and pigmy hog. Rhinoceros, too, would have been exterminated but for the special protection afforded to them. The majestic lions, which used to be common in North India and numbered 250 in 1955, are now restricted to the Gir Forests of Gujrat State. A small part of the total number of black-andwhite coated spiral horned black buck remain and if appropriate measures for its perpetuation and protection are not taken it may, too, quite soon become as dead as the dodo.

Fortunately 70 sanctuaries sprawling all over India and covering an area of approximately 50,000 kilometers are contributing to the preservation of Indian wild life. Apart from the Gir Forests, where the Indian lion is found and raised the best known among them are Kaziranga, Manes, sonai rupai, Orang Reserve, Lakhow Reserve in Assam state and Jaladpara in Bengal, which are restoring the world-known Indian one-horned rhinoceros.

Assam sanctuaries in collaboration with the sanctuaries like Madumalai (Madras), Periyar (Kerala), Jaladpara (Bengal) and the sanctuaries of Utter Pradesh are providing refuge to the Indian wild elephant. Wild buffaloes and Indian bison (gaur) are protected in the sanctuaries of Assam, Madumalai and Periyar. Deer are preserved in Dachigam, Rajpari, Chununai (Jammu and Kashmir) and other north Indian sanctuaries. The rare animals like brow-antlered deer and the banting or Tsaine are getting special attention in Keibal sanctuary in Manipur.

The avian fauna is preserved in sanctuaries like $\mathrm{Keoladeo}$ Ghana (Rajasthan), Vedathngal (Madras), Serin a g p a t a m and Ranganthittoo (Mysore), and Bhupender Sagar near Patiala (Punjab).

There is a fish sanctuary near Ram Nath Pur in Mysore state.

In addition to these sanctuaries, there are about 20 zoological gardens and many museums in the various states of India where we can observe and admire wild life. 
